\title{
Evaluating Key Capabilities for Developing Global Collaborative Networks Using a Multi-Layer Decision-Making Approach
}

\begin{abstract}
Purpose. This paper proposes a multi-layer hybrid decision-making approach to evaluate the capability alternatives for developing a collaborative network to operate in the international market.

Method. The present study is contextualised in the Iranian pistachio export industry. An extensive review of the state-of-the-art literature on supplier collaboration was conducted to identify key capabilities that are essential to establish a collaborative network. The set of defined capabilities were then optimised through interviews with fourteen experts from the relevant industry, academics, and export authorities. A combination of the fuzzy Delphi method and the best-worst method (BWM) approach were respectively used to reduce the number of capability alternatives and assign priority weights to these alternatives. Subsequently, a weighted aggregated sum product assessment method (WASPAS) was employed to rank and evaluate the ability to creating a collaborative network for the export of pistachio.

Findings. From the extant literature review, eighteen capabilities for the formation of collaboration networks in the international markets were identified. Then, the prominent indicators in forming a global network were extracted. After ranking the top pistachio export countries/regions to formalise an efficient collaborative network, it was revealed that although Iran exports approximately $30 \%$ of the global market; however, it falls behind the USA and EU. The competitors have scored higher in critical criterias including "trust and commitment", "strategy and management", "managerial control and standardisation" and "financial resources".

Originality. The proposed hybrid approach encompassing Fuzzy Delphi-BWM-WASPAS offers to solve the capability evaluation and selection and ranking the possible alternative to formalise a collaborative network in an integrated fashion. This combination of methods is capable to first identify the most important factors, then measuring their importance, and eventually rank the possible alternatives. The suggested framework provides an approach to deal with the uncertainty of global collaborative network formation.
\end{abstract}

Keywords. Network Collaboration; Export Network; Fuzzy Delphi Method; Best Worst Method; weighted aggregated sum product assessment.

Paper Type: Research Paper 


\section{Introduction}

In recent years, economic organisations have been affiliated with contractual agreements through collaborative networks. These agreements have become more critical in emerging markets and economies (Baier-Fuentes et al., 2021). Collaboration networks present an opportunity in which business partners can develop short or long-term collaboration to achieve personal and mutual goals (Ramayah et al., 2011). In other words, collaborative networks are built amongst companies that are independent, geographical-decentralised, and heterogeneous from the viewpoint of workplace, culture, social capital, and aims. Nowadays, more companies are aware of and motivated by the application of common platforms as business tools. These common platforms allow groups of companies to level up bargaining and competing (Graça and Camarinha-Matos, 2017; Haque and Islam, 2018). Companies participate to gain mutual goals, develop processes or joint products, distribute the cost of investment, reduce risk, and share information (Jensen, 2017; Herczeg et al., 2018). Considering the role and positive effects of collaborative networks on newfound economies and due to management of the workflow within organisations, the domination of a service-centreed approach, expansion of current novel markets, and adoption of a modern organising system, it is crucial to study, create, analyse and promote collaborative networks to employ the advantages of economic progress (Lv and Lin, 2017; Amoozad Mahdiraji et al., 2018).

Foreign markets demand special and strict requirements to operate in. These are not only dictated by consumers' wishes but also influenced by the technical and regulatory obligations of the destination countries. The firms interested to export, should diagnose the destination market, contact local distributors and/or major consumers, be informed about customer's specifications, adapt quality and prices, and provide the opportunity to meet local trends and seasons. In a vast majority of cases, companies should get certification that their production methods are following the particular technical and environmental standards of the destination country. More than often, the demands of the local knowledge, the distribution network, the marketing channels, the logistics and customer service, and the cost of facing these challenges is more than the ability of a single company (UNIDO, 2003). Economists have been always minded about the role of export to expedite economic growth (Bryant, 2019). However, a successful presence in a foreign market is much more complicated and costlier than the domestic market. The efforts to export would fail without destination knowledge, planning, and collaboration with local agents. According to pieces of evidence, export companies can face higher failure rates (Unido, 2003; Bryant, 2019). With this in mind, developing a successful company exporting agriculture like pistachio from a developing country like Iran poses various strategic and operational challenges. In this context, this research identifies and evaluates key capabilities for the formation of collaborative networks. This can provide useful guidance for practitioners as formation in collaborative networks deal with high levels of uncertainty (Nohrstedt and Bodin, 2019). Being aware of key capabilities in uncertain circumstances helps the practitioners and authorities to invest in appropriate areas and as a result form an efficient and effective collaborative network. Furthermore, comparing the status of Iran with other competitors in the pistachio market demonstrates the strength and weaknesses of Iran for planning any regional or international collaboration. 
As mentioned earlier, companies seek to engage in collaborative networks to address the deficit in their key capabilities to improve agility and flexibility. Collaborative networks are also required to access knowledge, marketing channels, legal systems, or compliance while operating in foreign markets. The key question is 'how can companies choose from a selection of right partners with the right capability set to engage in a collaborative relationship in the international market?' Besides, identifying these key capabilities to create a collaborative network with other suppliers, manufacturers, distributors, competitors, wholesalers, etc. could help an organisation to concentrate on critical points for development. The importance and challenges of forming collaborative networks in uncertain conditions have been discussed and highlighted by many researchers (Bodin and Nohrstedt, 2016; Mukherjee, 2017; Nohrstedt and Bodin, 2020; Rodgers et al., 2020) and many others have suggested methods to deal with these situations. In this regard, Salamat et al. (2018) used a fuzzy probabilistic approach for partner selection for developing an international strategic alliance. Moreover, Brown et al. (2019) provided a qualitative approach to identify key capabilities in the marketing function of a company. However, to the knowledge of the authors, previous research works lack an inclusive framework to extract the key capabilities, determining the importance of them and ultimately evaluating the possible alternatives in creating a collaborative network. Furthermore, in agricultural products and especially Pistachio, and for emerging economies such as Iran, no similar research works have been identified. This research extends previous efforts by first proposing a multi-layer Fuzzy Delphi decision-making tool for key capabilities selection to deal appropriately with intuitive and uncertain information. Subsequently, the authors offer the best and worst method (BWM) technique to cross-examine the quality of these results by removing in-consistency associated with the above method. Finally, the authors employ the Weighted Aggregated Sum Product Assessment (WASPAS) method to rank the possible alternative countries/regions to formalise the Pistachio collaborative network.

In the rest of this paper, at first, a summary of the literature review is provided to identify the key capabilities required for shaping a collaborative network. Subsequently, theoretical foundations explaining the fuzzy Delphi, BWM, and WASPAS methods are given. Subsequently, the implementation of these methods is illustrated, at first, by identifying and reducing the capability choices, and secondly, ranking the possible alternatives (countries or regions) to create an international collaborative network. Finally, the discussion is provided and conclusions are made.

\section{Collaborative Networks}

Collaboration is the process in which independent casts interact by formal or informal negotiations, set common rules, found structures based on their relations, and determine the ways to decide on joint issues. The collaboration process contains shared norms and optimal mutual interplay (Thomson and Perry, 2006). Although there are different ways to define collaboration, at times it is confused with related concepts such as information exchange, coordinated network, co-operated network, etc. (Camarinha-Matos and Afsarmanesh, 2006). Note that the integration level in terms of goals and identity and working together increases as moving along the continuum of 'network', 'coordinated network', 'co-operative network', and 'collaborative network' that is the most integrated coalition type of network. The network partners are expected 
to work very closely together, have to join goals, form joint identities, align their activities in a true partnership manner, and undertake co-creation work. An export consortium can be identified as an official midterm or long-term strategic cooperation that acts in the role of the provider of specialised services to simplify access to foreign markets (UNIDO, 2003). Some advantages of such clusters include accessing on-time market information, the ability to enter a foreign market, availability of cost-effective technical support, and access to local marketing and advertisement channels (Moosavi and Noorizadegan, 2009). In Table 1 the authors provide a summary of the previous literature in the field of a collaborative network. It identifies the type of network, what has been examined and what were the key findings of this research. The authors clustered the literature into three types. Firstly, the authors identified the research and different types of modeling methods employed to study the impact of different parameters on collaborative networks. Secondly, the authors grouped the papers that were involved with the identification of critical success factors for the formation of a collaborative framework. Thirdly, the authors clustered papers that described various case studies that concerned the formation and outcomes of collaborative frameworks. The literature review transpired that there are only a few case studies about the formation of collaborative networks within the context of developing countries, especially in the field of agriculture. Based on this, this research focused on the formation of collaborative networks for the export of pistachio from Iran. Pistachios constitute a significant share of the Iranian agricultural export and hence have particular importance for Iran's GDP. However, despite the high quality of the product, the industry faces significant challenges due to competition and having a weak supply chain and collaborative network. This research proposes a structured framework to identify the critical factors influencing the formation of network collaborations. Alongside this, the paper provides a ranking mechanism to benchmark Iranian export performance against other bigger players, namely, the USA, Turkey, and EU in the export market.

\section{Insert Table 1 Here}

According to Table 1, previous research works related to the formation of collaborative networks have mostly employed qualitative methods based on interviews, literature review, and case studies (e.g. Brown et al., 2019; Lyu et al., 2019; Schardosin et al., 2020). Besides, some other scholars have employed soft operations research methods (e.g. SNN) or statistical-based models (e.g. PLS, SEM) to examine critical factors in collaborative network formation (e.g. Papa et al., 2020; Wang and $\mathrm{Hu}, 2020)$. Nevertheless, to the best knowledge of the authors, a hybrid decision-making-based approach to identify critical factors in collaborative network formation, measure their optimal importance by mathematical modeling, and rank the most appropriate alternative to form the collaborative network has not been designed and employed. Furthermore, the collaborative networks formation in the emerging economies and especially in the agricultural products and sector has not been scrutinised via these models previously. Hence, this paper introduces a hybrid multi-layer decision-making approach to examine the establishment and development of a collaborative network and provide guidelines for practitioners and managers in the field. Some researchers have used a multi-criteria decision-making approach (MCDM) for partner selection in collaborative networks (Salah et al., 2017; Hsu and Lee, 2010; Zadeh, 1965; Kumar and Dash, 2017). However, most of these relate to selecting partners for technology development or relate to inter-modal transport selection (Wang and Yeo, 2018). 
There are some examples of using the MCDM approach in the service sector (Zhang, 2017). However, the authors propose a multi-layer decision-making framework for identifying and evaluating collaborative network formation capabilities employing the fuzzy Delphi method and Best-Worst Method (BWM). Moreover, the ability to create a collaborative network in four regions and/or countries including the EU, Iran, Turkey, and the United States of America is ranked employing the Weighted Aggregated Sum Product Assessment (WASPAS) method.

\section{Methodology}

For this research, the authors first reviewed the literature to identify the key selection criteria for forming collaborative networks in the Pistachio industry. This selection was later refined through the adoption of a fuzzy-Delphi approach to weight the recognised criteria with the help of a group of experts. The data gathering of the present research was based on related literature and experts' opinions. Fourteen experts were selected for this purpose using the snowball technique (Etikan et al., 2016). These experts were either CEO/senior managers from the pistachio industry, university academics who had international export knowledge, or practitioners who were from government organisations promoting export for the country. The current study contained 4 research stages. Each stage consisted of some steps as illustrated in Figure 1. These are described below.

\section{Insert Figure 1 Here}

\section{Phase 1. Initial Screening}

In this phase, a thorough literature review was undertaken to identify the main collaborative capabilities and select the most highly-referenced enablers. This phase utilised secondary data that served as the basis for the subsequent stages of the research.

\section{Phase 2. Data Gathering}

Considering the national and industrial relevance of this research, at first, a list of experts (owners/managers) in the pistachio export industry was selected. It was recognised that although these experts were very knowledgeable of the product's quality and internal market, they had limited knowledge of how to conduct business in the international market. Therefore, the authors included officials from the Ministry of Industry, Mine and Trade (MIMT), export office, who had a good understanding of the industry, and the export process. Realising the fact that these experts and officials had little knowledge of how to develop international partnerships and the value of creating networks, the authors invited several local academics who had published in this area. In each case, the researchers started with identifying one person initially and used the snowballing technique to grow the sample size.

Accordingly, fourteen experts including the CEOs of some of the most active export companies of pistachio (five experts), university professors with the research focus on collaborative networks (four members), and members of the Iranian union of dried fruit exporters and their consultants from the Ministry of Industry, Mine and Trade (MIMT) (five experts) were selected and invited to participate in the study. Afterwards, the 14 experts were divided into 7 groups. Each pair included one academic, who was made aware of the methodology and domain 
knowledge of partnership, and one expert either from industry or an official from the authority. Notably, based on the combination of each focus group including at least one manager/owner from the pistachio export industry; or at least one official from the export office, and at least one local academic with publications in the collaborative networks formation area, all focus groups were familiar with collaborative networks, international markets and close to the pistachio industry based on their members. As the capabilities are regarding international collaborative networks and considering the international experience of the managers and professors that participated in this research, and as the foreign international managers were not accessible, the experts were limited to Iran as an emerging economy and a leader in the pistachio industry. Table 2, explores the experts profile.

\section{Insert Table 2 Here}

After expert selection and designing focus groups, the authors communicated with the focus groups in three stages including data gathering for the Delphi-Fuzzy, BWM, and WASPAS. In each stage of data gathering, one of the researchers participated as the mentor and the facilitator of the session and asked the two members of the focus group to complete the relevant questionnaire. The sessions were all face to face considering social distancing due to the COVID19 pandemic and the questionnaires were all Likert-scale including linguistic terms as mentioned in Table 3. At this stage, the authors used the Delphi-Fuzzy method to extract the most important factors from the initial list (gathered from the literature review) based on the consensus among the experts. With the help of the experts, the authors were able to reduce the selection of capabilities that are essential for creating a collaborative network.

\section{Phase 3. Capability Analysis}

After identifying the most relevant capabilities in Phase 2 thru the fuzzy-Delphi method, the authors were required to determine the importance of each of these in order. Therefore, the authors assigned weights to each of these capabilities for further analysis. The factors weights resulted from the Fuzzy Delphi method are usually close to each other; thus, the distinction power of the criterias is not measured clearly. Moreover, the fuzzy-Delphi does not provide a priority list to rank these capabilities/factors according to their relative importance (Mahdiraji et al., 2020). The authors; therefore, introduced a hybrid BWM-Delphi weight to calculate the weights of these capabilities. The researchers combined the weights obtained from BWM and fuzzy Delphi, by the arithmetic mean and the comparisons were presented to reveal the most significant capabilities. Again, each pair of experts were given a set of structured questionnaires to provide an agreed response to each criteria for forming a collaborative network. In this regard, the experts' opinion was emanated from seven groups mentioned in the BWM step in a Likert spectrum ranging from 1 to 9 .

\section{Phase 4. Formation}

This study proposes a multi-layer hybrid decision-making approach to evaluate the alternatives for forming and developing a collaborative network to operate in the international market of agricultural products. Hence, this leads to prioritise the top countries found on identified capabilities to form a collaboration. Ranking these countries conducts a benchmarking model to 
establish collaborative networks. In this phase, fourteen experts took part in conducting a benchmarking exercise to rank the top four export countries in the world by analysing their capabilities to form a collaborative network for export purposes. The best country can be applied as a highlighted benchmarking model in various dimensions for the establishment of collaborative networks. The countries included the top pistachio export countries/region including the USA, Turkey, EU, and Iran. Experts opinions were collated from focus groups and summarised using the WASPAS method. The analyses conducted with the Fuzzy Delphi, Best Worst Method, and WASPAS methods are explained in detail in the following sections.

\subsection{Fuzzy Delphi Method}

The Delphi method was first introduced by Helmer and Dalkey of the RAND Corporation (Humphrey-Murto and de-Wit, 2019). This is a scrolling technique based on experts' opinions that holds 3 main features, including anonymous replies, repeat, and controlled feedback, and statistical group responses (Hsu and Lee, 2010). Whilst collecting human opinion there is usually a degree of uncertainty and dealing with concepts that do not fall within 'yes' or 'no' answers. Moreover, a Likert scale type of measurement cannot capture some probabilistic answers that are based on imprecise information. Therefore, the Delphi method is combined with Fuzzy Theory (Zadeh, 1965) to cover the aforementioned weaknesses. The fuzzy Delphi method has been applied to various types of research in recent years. For example, Abdullah and Siraj (2018) and used the fuzzy Delphi method to evaluate English learning strategies on a mobile platform. Kumar and Dash (2017) employed a combination of fuzzy Delphi and generalised fuzzy TOPSIS to evaluate the flexibility dimensions of technological service in online stores. In the field of clean products, Zhang (2017) used fuzzy Delphi-AHP to measure regional low-carbon tourism. Wang and Yeo (2018) selected an intermodal route for cargo transportation from Korea to Central Asia by using fuzzy Delphi- fuzzy ELECTRE. In another research, Ocampo et al. (2018) applied fuzzy Delphi to find sustainable ecotourism indicators in the context of the Philippines. In this research, the fuzzy Delphi method was implemented as follows:

- Each linguistic term was coded through a triangular fuzzy number (TFN). An advisable linguistic Likert spectrum was developed as illustrated in Table 3.

\section{Insert Table 3 Here}

- Fuzzy values were aggregated by equation (1) (Hsu et al., 2010).

$$
F_{A G R}=\left(\min \{l\},\left\{\frac{\sum m}{n}\right\}, \max \{u\}\right)
$$

In Eqn. (1) $(l, m, n)$ denotes the TFN appointed by experts, and $n$ indicates the number of experts.

- The values obtained in Eqn.1 were defuzzified using Eq. (2) (Abdullah and Siraj, 2018) to get a crisp value.

$$
\text { crisp }=\frac{L+2 M+U}{4}
$$

- A limit value was considered for defuzzification. In case the crisp value was greater than the limit, the capability criteria was confirmed, otherwise, it was deleted from the initial list gathered from the related literature or interviews. Succeeding the cessation, the 
criteria were admitted that got the defuzzified value more than the threshold to accept (S). In this paper, $S$ was considered 0.8 .

\subsection{Best Worst Method}

Rezaei (2015) proposed BWM to assign weights to criteria. Although BWM is a relatively new method, several variations have been suggested to modify it. These include linear BWM (Rezaei, 2016), fuzzy BWM (Guo and Zhao, 2017; Wang et al., 2018), Euclidean BWM (Kocak et al., 2018), and multiplicative BWM (Brunelli and Rezaei, 2019). BWM has been utilised in various types of research. Note that the applications of this method have been analysed and presented (Amoozad Mahdiraji et al., 2018; Mi et al., 2019); besides, the hesitant version of this method was recently introduced (Mi and Liao, 2019; Luo et al., 2020). In this research, the authors have employed the Non-Linear BWM version as explained below (Rezaei, 2015).

- A set of decision criteria were sifted out of all criteria $\left(\left\{\mathrm{C}_{1}, \mathrm{C}_{2} \ldots . \mathrm{C}_{\mathrm{n}}\right\}\right)$.

- Experts or focus groups selected the best and the worst criteria. No comparison was performed in this step;

- Experts or focus group determined the preference of the best criteria against the overall criteria by selecting a number ranging from 1 to $9\left(A_{B j}=\left(A_{b 1}, A_{b 1}, \ldots, A_{b n}\right)\right)$.

- Experts or focus group determined the preference of all criteria over the worst criteria, and was again, by selecting a number from 1 to $9\left(A_{j w}=\left(A_{1 w}, A_{2 w}, \ldots, A_{n w}\right)\right)$;

- The nonlinear (NLP) model (Eq. (3)) was solved with the LINGO software to attain the optimal weights for each expert group $\left(\left\{\mathrm{W}_{1}, \mathrm{~W}_{2}, \ldots, \mathrm{W}_{\mathrm{n}}\right\}\right)$ when $\xi$ is the difference variable of the results from the experts comparisons, and $W_{j}$ is the weight of the $j^{\text {th }}$ criteria, $W_{B}$ is the weight of the best criteria and $\mathrm{W}_{\mathrm{W}}$ is the weight of the worst criteria.

$$
\begin{aligned}
& \min \xi \\
& \text { st: } \\
& \left|\frac{W_{B}}{W_{j}}-A_{b j}\right| \leq \xi ; \quad \text { for all } j \\
& \left|A_{j w}-\frac{W_{j}}{W_{W}}\right| \leq \xi ; \quad \text { for all } j \\
& \sum W_{j}=1 \\
& W_{j} \geq 0
\end{aligned}
$$

- The compatibility ratio of comparisons was computed by Eq. (4) where $\xi^{*}$ is the optimal value of $\xi$ emanated from solving model (3) via LINGO.

$$
C R=\frac{\xi^{*}}{C I}
$$

$C I$ is the compatibility index, which is determined based on the preference of the best criteria over the worst criteria $\left(\mathrm{A}_{\mathrm{BW}}\right)$. $C I$ values were elaborated in Table 4 . It is preferred that the value of $\mathrm{CR}$ for each expert result is less than 0.2. Higher values are not recommended and the expert should fill the questionnaire again or be replaced by another possible expert (Amoozad Mahdiraji et al., 2018; Mahdiraji et al., 2019; Mahdiraji et al., 2020). In this study, three focus groups were required to fill in the questionnaire for the second time.

\section{Insert Table 4 Here}




\subsection{Weighted Aggregated Sum Product Assessment}

WASPAS is an MCDM technique introduced by Zavadskas et al. (2012) that combines a weighted sum model (WSM) and a weighted product model (WPM). Several types of research works have applied the WASPAS technique. More recently, Mahmoudi et al. (2019) used this method and developed it with intuitionistic fuzzy information. In the present research, WASPAS was used as described by Zavadskas et al. (2012) by the following steps:

- An experts' decision matrix was prepared for normalisation. Profit criteria were normalised by equation (5) while cost criteria were normalised by equation (6).

$$
\begin{aligned}
\bar{X}_{i j} & =\frac{X_{i j}}{\max _{i} X_{i j}} \\
\bar{X}_{i j} & =\frac{\min _{i} X_{i j}}{X_{i j}}
\end{aligned}
$$

Remark that $X_{i j}$ is the value of $i_{\text {th }}$ alternative based on $j_{t h}$ criteria.

- Relative priorities of the alternatives were calculated built on WSM by Eq. 7 .

$$
Q_{i}^{(1)}=\sum_{j=1}^{n} \bar{X}_{i j} W_{j}
$$

Notice that $W_{j}$ referred to the weight of the $j_{t h}$ criteria.

- Relative priorities of the alternatives were computed placed on WPM by Eq. 8 .

$$
Q_{i}^{(2)}=\prod_{j=1}^{n}\left(\bar{X}_{i j}\right)^{W_{j}}
$$

- The results of WSM and WPM were merged as follows.

$$
Q_{i}=\lambda Q_{i}^{(1)}+(1-\lambda) Q_{i}^{(2)}
$$

Optimal $\lambda$ was measured to operate (Eq. 9) via the below steps.

I. Estimates variance of initial criteria were computed applying Eq. 10.

$$
\sigma^{2}\left(\bar{X}_{i j}\right)=\left(0.05 \bar{X}_{i j}\right)^{2}
$$

II. The estimated variance of relative priorities was determined by Eq. 11 for WSM and Eq. 12 for WPM.

$$
\begin{aligned}
& \sigma^{2}\left(Q_{i}^{(1)}\right)=\sum_{j=1}^{n} W_{j}^{2} \sigma^{2}\left(\bar{x}_{i j}\right) \\
& \sigma^{2}\left(Q_{i}^{(2)}\right)=\sum_{j=1}^{n}\left\{\frac{\prod_{j=1}^{n}\left(\bar{x}_{i j}\right)^{w_{j}} w_{j}}{\left(\bar{x}_{i j}\right)^{w_{j}}\left(\bar{x}_{i j}\right)^{\left(1-w_{j}\right)}}\right\}^{2} \sigma^{2}\left(\bar{x}_{i j}\right)
\end{aligned}
$$

III. Optimal $\lambda$ was calculated employing Eq. 13 as follows.

$$
\lambda=\frac{\sigma^{2}\left(Q_{i}^{(2)}\right)}{\sigma^{2}\left(Q_{i}^{(1)}\right)+\sigma^{2}\left(Q_{i}^{(2)}\right)}
$$

\section{Case Study and Results}

As previously discussed, the authors conducted an extensive review of the literature to identify the main capabilities that are recognised as essential to effectively developing a collaborative 
network. The researchers identified eighteen capabilities that are frequently referenced in academic literature. These capabilities were summarised along with the constituent assets and characteristics, frequency of referencing, and relevant referencing in Table 5, which illustrates these capabilities in descending order.

\section{Insert Table 5 Here}

Pistachio seeds are part of the cashew family. They have been one of the favorite products in Iran for many centuries as they have been consumed for their taste and nutritional value in food desserts and as a snack. The geographical characteristics, soil chemistry and dry and sunny conditions provide a unique environment for Iran to produce the finest quality pistachios. Nearly $45 \%$ of this product is originated from the province of Kerman. Iran is one of the biggest producers of pistachio, which is its second-largest export commodity after crude oil. Despite a recent decline in the worldwide production of the crop, the export volume of Iranian pistachio has been 135 thousand tons from March 2016 to March 2017. Iranians international market share in the pistachio export industry has decreased since 1975 whilst competitors such as the USA, EU, and Turkey have increased their market share over time. Pistachio makes up a $1.5 \%$ share of the total GDP in Iran. While domestic consumption accounts for only 10\%, the bulk of it is exported annually mainly to Hong Kong and Vietnam. The highest revenue for pistachio export in Iranian history is approximately two billion US dollars. The quality, taste, geopolitical circumstances and low freight costs are the key factors driving this export. Figure 2 illustrates the production volume (in thousands of tons) of this commodity during 2012-2017 for the three main global competitors.

\section{Insert Figure 2 Here}

Recently, the pistachio industry in Iran has declined due to droughts and a weaker demand arising from higher tariffs imposed from its importers. Currently, Iran sits second to the USA in the worldwide export metric for this product. There is a concern in the academic and professional circles that if this decline continues, Iran will be unable to sustain its competitive edge in the market. This will impact 130 thousand strong workforces employed in this industry. Several factors are attributed to this decline. These include old methods of agriculture, weak supply chain partnerships amongst producers and exporters (Herczeg et al., 2017; Mahdiraji et al., 2019), poor quality of packaging and marketing and weaker international collaboration in the destination countries. Under the sponsorship of the 'Ministry of Industry, Mine and Trade' and the 'Ministry of Agricultural' several think tanks comprising academics, professionals and producers were established. Their key recommendations included establishing industrial zones or clusters similar to Dubai (Hajiagha et al., 2018; Brown et al., 2019) with appropriate partners in the domestic market and creating international collaborative networks (Beheshti et al., 2016; Graça, and Camarinha-Matos, 2017) as the main strategies to grow and sustain the export level (Statistical Centre of Iran, 2019; Islamic Republic of Iran Customs Administration, 2019; Central Bank Iran, 2019).

In the second phase, the experts (as were introduced in section 3. Methodology) pointed out the determinant factors for creating a collaborative network employing the Likert spectrum 
described in Table 2 and integrated by equation (1). Subsequently, these values were defuzzified by using equation (2), see Table 6 .

\section{Insert Table 6 Here}

The limit value was determined by 0.8 to sieve the factors. The factors with less defuzzified value were omitted and highlighted in Table 6. The fuzzy Delphi technique was run 2 times for each expert and the differences were less than 0.1. The defuzzified values were normalised to extract the weights of the factors. The results are detailed in Table 6 . In the third phase, a questionnaire was distributed among experts to perform the BWM analysis. Initially, the experts selected the best and the worst criteria in each double group. After that, the preference of the best criteria over other and other criteria's over the worst were determined by each group. The experts were divided into seven groups consisting of two members. The model of equation (3) was composed and solved by LINGO 17.0 software for each group and the results, see Table 7. In the final column, the arithmetic average of the weights that resulted from each group was computed as the final weight of each criteria in the BWM method.

\section{Insert Table 7 Here}

Furthermore, the compatibility rate for each group of experts was computed by equation (4) and illustrated in Table 7 (last row). As indicated in Table 7, the consistency ratio of all experts who participated in the BWM stage was acceptable; hence, the results were validated. At the end of this phase, the weights derived by fuzzy Delphi and BWM were integrated via arithmetic mean and delineated in Table 8 and Figure 3.

\section{Insert Table 8 Here}

\section{Insert Figure 3 Here}

The analyses suggest that trust and commitment, strategy and management, financial resources, and standardisation are the most determinant factors influencing the successful formation of a prominent collaborative network. In the final stage, the matrix of 4 competitors' status including the EU, Iran, Turkey, and the United States of America was constructed considering the experts' opinions average. These countries own the highest market share of pistachio production and export among the world, i.e. USA 52\%, Iran 26\%, Turkey 3\%, EU 6\%, and other countries $13 \%$. According to the experts, Iran is better in some factors that include holistic view and synergies, experience exchange, and financial resources. This derives from its background in the pistachio industry and high-volume production. On the other hand, the United States of America is considered more prominent in efficiency and knowledge as well as having higher skills in some other factors, e.g. standardisation and strategy and management. The decision matrix was normalised employing equations (5) and (6) and the results are presented in Table 9 alongside the original decision matrix and the variance matrix. Note that all of the capabilities emanated and evaluated in Table 8 are considered as benefit criteria; thus, higher values for each alternative regarding them are desirable. The values in the initial decision matrix were emanated from the average score of evaluating each country according to each networking capability from the group of experts. 


\section{Insert Table 9 Here}

Relative priorities of criteria were calculated using WSM with equation (7) and WPM with equation (8). Afterward, the variances of criteria were estimated applying equations (9) to (13). In the following table, the variances of the estimates of relative priorities were computed by applying equation (11) in WSM and equation (12) in WPM. Optimal $\lambda$ was determined with equation (13) and applied in equation (9). Eventually, the countries were ranked using equation (9), which was elaborated in the last three columns of Table 10.

\section{Insert Table 10 Here}

The results demonstrated that the United States possessed the most ability to create collaboration networks for pistachio exports. Although Iran controls nearly $30 \%$ of the global market, the expert opinions and the WASPAS method results suggest that Iran ranks lower than even the EU, with only a $6 \%$ market share. These results indicate that authorities and executive managers of the Iranian pistachio industry consider other countries as more capable and reliable in forming collaborative networks.

\section{Discussion and Implications}

This article mainly focused on designing a multi-layer hybrid decision-making approach consisting of Fuzzy Delphi, BWM, and WASPAS to first screen and evaluate the capabilities for forming and developing a collaborative network to operate in the international markets; moreover, to identify and rank the possible alternatives (countries, regions) to formalise the collaboration in pistachio industry.

Various research works have focused on the pistachio industry and even in the emerging economy of Iran (Sedaghat, 2019; Darijani et al., 2019), mainly focused on the productivity factors or the resilience of the industry. However, there are very limited research and evidence on the key capabilities or decision-making issues that may contribute to establishing effective collaborative networks in this industrial sector. Thus, the results of this research are based on a novel multi-layer decision-making approach and not comparable with previous research works in the Pistachio sector. On the other hand, the results emanated from this research in identifying key capabilities in collaborative network formation align with previous articles. As a result of the Fuzzy Delphi method, then key capabilities were extracted as prominent factors previously mentioned in a systematic literature review research (Song et al., 2019). Factors including trust and commitment, holistic view and synergies, experiences exchange, history, and identity were all previously identified by other scholars in Asia (e.g. Segato and Raab, 2019; Tan et al., 2020) and Europe (e.g. Bauza and Ruiz, 2020). Other factors were also previously used by other scholars as mentioned in Table 4 (Petter et al., 2014). From a technical point of view, A hybrid Fuzzy Delphi-BWM approach was employed to determine the importance of key capabilities. The results of this approach are not comparable with other similar methods such as AHP. In other pairwise comparison-based methods, the consistency of the experts, the discrimination power of the results, and the participation of experts would have been affected negatively (Ishak, and Akmaliah, 2020). As an illustration, with 18 criteria, 153 comparisons would have been expected. Moreover, with 10 criteria, 45 pairwise comparison is necessary. However, in this research, only 17 comparisons were considered in the BWM method. With 45 or 153 pairwise 
comparisons, the expert's consistency index usually is rejected; nonetheless, in BWM by employing only 17 comparisons, the consistency ratio of the expert's opinion was calculated and verified. These prove that the weight of the key capabilities is reliable and also resulted from an efficient method.

The results of this research are debatable from two perspectives, the key capabilities, and the collaborative network creator ranking. First, according to Table 8 , the results denote that trust and commitment, strategy and management, financial resources, managerial control, and standardisation are the determinant capabilities (covering nearly 60\%) in forming a collaborative network in the Pistachio industry. These factors indicate that to form a global collaborative network in the studied industry, trust and commitment have the highest priority (Bianchi and Saleh, 2020). Besides this strategic capability, three managerial aspects are ranked next including finance, standardisation, and control (Wen et al., 2020).

According to these facts, in case an emerging economy such as Iran is eager to form a collaborative network in the Pistachio industry, this country needs to build trust at an international level. Due to political problems with the United States and the United Kingdom and some other European countries, forming a successful collaborative network in this industry seems impossible. Previous weak relationships with other parties and isolated political strategies, has made Iran not a safe and secure centre for collaborators. With these facts in mind and based on the expert's opinion, to change the current trend the industry and government authorities should focus on ten chosen criteria. By the current political behavior as described and international sanctions, the researchers believe that investing in other criteria leads to a waste of money and time. Thus, the authors predict that forming a successful global collaborative network for the Pistachio industry (or other possible industries) could only occur after creating trust and commitment with other members (domestically and internationally). Remark that even in financial resources the situation of this country is not suitable to form a network as their GDP and other economic indicators are in a poor situation. As a result, the vision of forming an Iranoriented collaborative network in the Pistachio industry seems unachievable unless solving their political relationship with the USA, EU and UK. As the ranking of network creators denotes in Table 10, Iran has been ranked third behind the USA and even the EU. The results elaborate that the United States has the most ability to create collaborative networks for pistachio exports. As previously mentioned in Figure 2, Iran was the first exporter and producer of the Pistachio industry decades ago. Although Iran is still exporting 30\% of global demand, this country is not able to build a productive and beneficial collaborative network with other activists in this market. As a result of this research presented, based on prominent figures of Pistachio in government, industry, and companies, even with this share of the market they fall behind the USA and EU for establishing collaborative networks. Note that, this paper does not investigate the partner selection, directly. However, the comprehensive pattern of this study can be employed to select the best benchmarking model among others which will be applied in various dimensions of collaborative networks including partner selection. 


\section{Limitations and Future Research}

The main goal of this research is to develop a pattern to evaluate the abilities to create collaborative networks in pistachio exports. For this purpose, 18 influential and highly-reference factors have been identified by reviewing the literature. Ten final factors have been elected rest on fourteen experts of the Iranian pistachio industry employing the fuzzy Delphi approach. In the following, the weights of these factors have been extracted applying integrated fuzzy Delphi and BWM. Eventually, the status of four nominated countries including the EU, Iran, Turkey, and the United States has been ranked by WASPAS. This paper is the first to propose a comprehensive multi-layer decision-making framework for developing a collaborative network in the international market. The research provides practitioners and companies who wish to establish a collaborative network of essential tools and guidance and enable them to gain a deeper insight into their own business.

This is research at the industry and national level using experts from only one country. To increase the validity of results in Delphi, BWM, and WASPAS steps, using the participation of international experts from different countries (at least competitors mentioned) is necessary. Moreover, in this research, a hybrid multi-layer decision-making approach has been introduced to find out the key capabilities in the formation of collaborative networks alongside ranking the most suitable alternative to formalise the network amongst the competitors. Nonetheless, collaborative networks include not only the same level partner and competitors but also suppliers, industrial partners, transformation, ect. (van den Heuvel et al., 2020). Hence, how to find out the key capabilities and rank the partners in the whole collaboration could be considered in the future by other scholars.

Furthermore, the other researchers can test the efficacy of this framework in different industries and different regions. Moreover, from a methodological perspective, there are some limitations regarding the proposed approach. First of all, triangular fuzzy numbers have been applied to consider the uncertainty in this research. However, there are many disadvantages to the fuzzy approach, for instance, the hesitation and intuition of the experts are not regarded. Thus, it is recommended that in future research works, scholars adopt hesitant fuzzy or intuitionistic fuzzy methods for their evaluation. Moreover, the scheduled approach only provides a list of determinant factors in forming collaborative networks and their importance. Nonetheless, the cause and effect relationship among the factors has not been considered. It is recommended that

in the future, scholars focus on applying methods such as interpretative structural modeling (ISM) or decision-making trial and evaluation laboratory (DEMATEL) to understand the relationship among the extracted factors and build a conceptual model to demonstrate how these factors influence each other. Furthermore, the extracted factors for network collaboration formation have been emanated from a literature review in this research. The authors recommend that other scholars try to employ other qualitative methods including grounded theory, theme analysis, etc. for identifying the key capabilities. Eventually, the ranking method applied in this research is a heuristic decision-making method and the reliability and validity of the results have not been investigated. The authors recommend that in future research works, scholars use methods with deterministic approaches including linear programming techniques for 
multidimensional analysis of preference (LINMAP) or simultaneous evaluation of criteria and alternatives (SECA) to result in more reliable ranks.

\section{References}

Adobor, H. (2011), Alliances as collaborative regimes: An institutional-based explanation of interfirm collaboration. Competitiveness Review, Vol. 21, No. 1, pp. 66-88.

Abdullah, and Siraj, S. (2018), Antecedents and consequences of the process of customer engagement through social media: An integrated conceptual framework. International Journal of Electronic Business, Vol. 14, No. 1, pp. 1-27. Abreu, A., Requeijo, J., Calado, J.M.F., and Dias, A. (2018), Control Charts to Support Trust Monitoring in Dynamic Logistics Networks. IFIP Advances in Information and Communication Technology, Vol. 534, pp. 499511 .

Al Hattab, M. (2021), The dynamic evolution of synergies between BIM and sustainability: A text mining and network theory approach. Journal of Building Engineering, Vol. 37, pp. 102159.

Amoozad Mahdiraji, H., Arzaghi, S., Stauskis, G., and Zavadskas, E.K. (2018), A hybrid fuzzy BWM-COPRAS method for analyzing key factors of sustainable architecture. Sustainability, Vol. 10, No. 5, pp. 16-26.

Andres, B., Ferrada, F., Poler, R., and Camarinha-Matos, L.M. (2018), A Modeling Framework to Assess Strategies Alignment Based on Collaborative Network Emotions. IFIP Advances in Information and Communication Technology, Vol. 534, pp. 349-361.

Appio, F.P., Martini, A., Massa, S., and Testa, S. (2017), Collaborative network of firms: antecedents and state-ofthe-art properties. International Journal of Production Research, Vol. 55, No. 7, pp. 2121-2134.

Baier-Fuentes, H., Guerrero, M., and Amorós, J.E. (2021), Does triple helix collaboration matter for the early internationalisation of technology-based firms in emerging Economies?. Technological Forecasting and Social Change, Vol. 163, pp. 120439.

Bauzá, F., Ruiz-Manzanares, G., Pérez-Sienes, L., Tarancón, A., Íñiguez, D., and Gómez-Gardeñes, J. (2020), Analyzing the potential impact of BREXIT on the European research collaboration network. Chaos: An Interdisciplinary Journal of Nonlinear Science, Vol. 30, No. 6, pp. 063145.

uBeheshti, M., Mahdiraji, H.A., and Zavadskas, E.K. (2016), Strategy portfolio optimisation: A copras g-modm hybrid approach. Transformations in Business and Economics, Vol. 15, No. 3C, pp. 500-519

Bell, M.L., Hobbs, B.F., and Ellis, H. (2003), The use of multi-criteria decision-making methods in the integrated assessment of climate change: implications for IA practitioners. Socio-Economic planning sciences, Vol. 37, No. 4, pp. 289-316.

Bianchi, C., and Saleh, M.A. (2020), Investigating SME importer-foreign supplier relationship trust and commitment. Journal of Business Research, Vo. 119, pp. 572-584.

Bodin, Ö., and Nohrstedt, D. (2016), Formation and performance of collaborative disaster management networks: Evidence from a Swedish wildfire response. Global Environmental Change, Vol. 41, pp. 183-194.

Bodin, Ö., Baird, J., Schultz, L., Plummer, R., and Armitage, D. (2020), The impacts of trust, cost and risk on collaboration in environmental governance. People and Nature, Vol. 2, No. 3, pp. 734-749.

Brown, D., Foroudi, P., and Hafeez, K. (2019), Marketing management capability: the construct and its dimensions. Qualitative Market Research: An International Journal, Vol. 22 No. 5, pp. 609-637.

Brunelli, M., and Rezaei, J. (2019), A multiplicative best - worst method for multi-criteria decision making. Operations Research Letters, Vol. 47, No. 1, pp. 12-15.

Bryant, C., 2019. Managing development in the Third World. Routledge.

Caglio, A., \& Ditillo, A. (2008), A review and discussion of management control in inter-firm relationships: Achievements and future directions. Accounting, Organizations and Society, Vol. 33, No. 7-8, pp. 865-898.

Cambra-Fierro, J., Florin, J., Perez, L., and Whitelock, J. (2011), Inter-firm market orientation as antecedent of knowledge transfer, innovation and value creation in networks. Management Decision, Vol. 49, No. 3, pp. 444-467. Camarinha-Matos, L.M., Fornasiero, R., Ramezani, J., and Ferrada, F. (2019), Collaborative networks: a pillar of digital transformation. Applied Sciences, Vol. 9, No. 24, pp. 5431.

Camarinha-Matos, L.M., Oliveira, A.I., Sesana, M., Galeano, N., Demsar, D., Baldo, F., and Jarimo, T. (2009), A framework for computer-assisted creation of dynamic virtual organisations. International Journal of Production Research, Vol, 47, No. 17, pp. 4661-4690.

Camarinha-Matos, L.M., and Afsarmanesh, H. (2006, June). Collaborative networks. In International Conference on Programming Languages for Manufacturing (pp. 26-40). Springer, Boston, MA.

Catalina, R. (2010), Need and potential risks of strategic alliances for competing successfully. Academy of Economic Studies, Vol. 13, No. 1, pp. 165-169.

Cha, K.J., and Kim, Y.S. (2018), Critical success factors for mutual collaboration with suppliers in IT outsourcing industry: a case study of a top IT outsourcing company in Korea. Enterprise Information Systems, Vol. 12, No. 1, pp. 76-95. 
Chang, S.C., Tu, C.J., Li, T.J., and Tsai, B.K. (2010), Social Capital, Cooperative Performance, and Future Cooperation Intention Among Recreational Farm Area Owners in Taiwan. Social Behavior and Personality: An International Journal, Vol. 38, No. 10, pp. 1409-1429.

Chow, R.P.M., and Yau, O.H.M. (2010), Harmony and cooperation: Their effects on IJV performance in China. Cross Cultural Management, Vol. 17, No. 3, pp. 312-326.

Darijani, F., Veisi, H., Liaghati, H., Nazari, M.R., and Khoshbakht, K. (2019), Assessment of Resilience of Pistachio Agroecosystems in Rafsanjan Plain in Iran. Sustainability, Vol. 11, No. 6, pp. 1656.

Dobrescu, R., Mocanu, S., Chenaru, O., Nicolae, M., and Florea, G. (2021), Versatile edge gateway for improving manufacturing supply chain management via collaborative networks. International Journal of Computer Integrated Manufacturing, pp. 1-15.

Etikan, I., Alkassim, R., and Abubakar, S. (2016), Comparision of snowball sampling and sequential sampling technique. Biometrics and Biostatistics International Journal, Vol. 3, No. 1, pp. 55-75.

Felzensztein, C., Gimmon, E., and Deans, K.R. (2018), Coopetition in regional clusters: Keep calm and expect unexpected changes. Industrial Marketing Management, Vol. 69, pp. 116-124.

Gomes-Casseres, B. (2015), The three laws of business combinations: How to create value by remixing assets. Strategy and Leadership, Vol. 43, No. 5, pp. 18-23.

Graça, P., and Camarinha-Matos, L.M. (2017), Performance indicators for collaborative business ecosystems Literature review and trends. Technological Forecasting and Social Change, Vol. 116, pp. 237-255.

Guo, S., and Zhao, H. (2017), Fuzzy best-worst multi-criteria decision-making method and its applications. Knowledge-Based Systems, Vol. 121, pp. 23-31.

Hajiagha, S.H.R., Mahdiraji, H.A., Tavana, M., and Hashemi, S.S. (2018), A novel common set of weights method for multi-period efficiency measurement using mean-variance criteria. Measurement, Vol. 129, pp. 569-581.

Haque, M., and Islam, R. (2018), Impact of supply chain collaboration and knowledge sharing on organizational outcomes in pharmaceutical industry of Bangladesh. Journal of Global Operations and Strategic Sourcing, Vol. 11 No. 3, pp. 301-320.

Herczeg, G., Akkerman, R., and Hauschild, M.Z. (2018), Supply chain collaboration in industrial symbiosis networks. Journal of Cleaner Production, Vol. 171, pp. 1058-1067.

Hjertvikrem, N., and Fitjar, R.D. (2021), One or all channels for knowledge exchange in clusters? Collaboration, monitoring and recruitment networks in the subsea industry in Rogaland, Norway. Industry and Innovation, Vol. 28, No. 2, pp. 182-200.

Hsu, Y.L., Lee, C.H., and Kreng, V.B. (2010), The application of Fuzzy Delphi Method and Fuzzy AHP in lubricant regenerative technology selection. Expert Systems With Applications, Vol. 37, pp. 419-425.

Huang, C., Chen, W., and Yi, H. (2020), Collaborative networks and environmental governance performance: a social influence model. Public Management Review, pp. 1-22.

Humphrey-Murto, S., and de Wit, M. (2019), The Delphi method-more research please. Journal of clinical epidemiology, Vol. 106, pp. 136-139.

Ishak, A., and Akmaliah, V. (2020, April). Technology assessment of liquid waste in rubber factory using analytical hierarchy process and promethee methods. In AIP Conference Proceedings (Vol. 2217, No. 1, p. 030059). AIP Publishing LLC.

Jensen, P.A. (2017), Strategic sourcing and procurement of facilities management services. Journal of Global Operations and Strategic Sourcing, Vol. 10 No. 2, pp. 138-158.

Jepsen, L.B. (2014), Critical Success Factors for Horizontal Logistics Collaboration. In Innovative Methods in Logistics and Supply Chain Management: Current Issues and Emerging Practices. Proceedings of the Hamburg International Conference of Logistics (HICL), Vol. 18 (pp. 459-477), Berlin: epubli GmbH.

Jiang, X., Li, Y., and Gao, S. (2008), The stability of strategic alliances: Characteristics, factors and stages. Journal of International Management, Vol. 14, No. 2, pp. 173-189.

Kimbu, A. N., Ngoasong, M. Z., Adeola, O., and Afenyo-Agbe, E. (2019), Collaborative Networks for Sustainable Human Capital Management in Women's Tourism Entrepreneurship: The Role of Tourism Policy. Tourism Planning and Development, Vol. 16, No. 2, pp. 161-178.

Kocak, H., Caglar, A., and Oztas, G.Z. (2018), Euclidean Best-Worst Method and Its Application. International Journal of Information Technology and Decision Making, Vol. 17, No. 5, pp. 1587-1605.

Kumar, A., and Dash, M.K. (2017), Using Fuzzy Delphi and Generalized Fuzzy TOPSIS to Evaluate Technological Service Flexibility Dimensions of Internet Malls. Global Journal of Flexible Systems Management, Vol. 18, No. 2, pp. $153-161$.

Leitner, R., Meizer, F., Prochazka, M., and Sihn, W. (2011), Structural concepts for horizontal cooperation to increase efficiency in logistics. CIRP Journal of Manufacturing Science and Technology, Vol. 4, No. 3, pp. 332337.

Li, J., Xiong, N., Park, J.H., Liu, C., Ma, S., and Cho, S. (2012), Intelligent model design of cluster supply chain with horizontal cooperation. Journal of Intelligent Manufacturing, Vol. 23, No. 4, pp. 917-931.

Lin, G.T.R., and Sun, C.C. (2010), Driving industrial clusters to be nationally competitive. Technology Analysis and Strategic Management, Vol. 22, No. 1, pp. 81-97. 
Lundberg, H. (2010), Strategic networks for increased regional competitiveness: Two Swedish cases. Competitiveness Review, Vol. 20, No. 2, pp. 152-165.

Luo, C., Ju, Y., Gonzalez, E.D.S., Dong, P., and Wang, A. (2020), The waste-to-energy incineration plant site selection based on hesitant fuzzy linguistic Best-Worst method ANP and double parameters TOPSIS approach: A case study in China. Energy, Vol. 211, pp. 118564.

Lv, Y., and Lin, D. (2017), Design an intelligent real-time operation planning system in distributed manufacturing network. Industrial Management and Data Systems, Vol. 117 No. 4, pp. 742-753.

Lyu, G., Chen, L., and Huo, B. (2019), Logistics resources, capabilities and operational performance. Industrial Management and Data Systems, Vol. 119 No. 2, pp. 230-250.

Mahmoudi, M., Mahdiraji, H.A., Jafarnejad, A., and Safari, H. (2019), Dynamic prioritization of equipment and critical failure modes. Kybernetes, Vol. 48, No. 9, pp. 1913-1941.

Mahdiraji, H.A., Kazimieras Zavadskas, E., Kazeminia, A., and Abbasi Kamardi, A. (2019), Marketing strategies evaluation based on big data analysis: a CLUSTERING-MCDM approach. Economic research-Ekonomska istraživanja, Vol. 32, No. 1, pp. 2882-2892.

Mahdiraji, H.A., Hafeez, K., Kord, H., and Kamardi, A.A. (2020), Analysing the voice of customers by a hybrid fuzzy decision-making approach in a developing country's automotive market. Management Decision.

Martin, N., Verdonck, L., Caris, A., and Depaire, B. (2018), Horizontal collaboration in logistics: decision framework and typology. Operations Management Research, Vol. 11, No. 1-2, pp. 32-50.

Mi, X., and Liao, H. (2019), An integrated approach to multiple criteria decision making based on the average solution and normalized weights of criteria deduced by the hesitant fuzzy best worst method. Computers and Industrial Engineering, Vol. 133, pp. 83-94.

Mi, X., Tang, M., Liao, H., Shen, W., and Lev, B. (2019), The state-of-the-art survey on integrations and applications of the best worst method in decision making: Why, what, what for and what's next?. Omega, Vol. 87, pp. 205-225.

Moeller, K. (2010), Partner selection, partner behavior, and business network performance: An empirical study on German business networks. Journal of Accounting \& Organizational Change, Vol. 6, No. 1, pp. $27-51$.

Moosavi, S.V., and Noorizadegan, M. (2009), Export Clusters (pp. 159-194), Physica-Verlag HD.

Msanjila, S.S., and Afsarmanesh, H. (2007), Modelling trust relationships in collaborative networked organisations. International Journal of Technology Transfer and Commercialisation, Vol. 6, No. 1, pp. 40-55.

Mukherjee, S. (2017), Collaborative governance strategies for a strategic offshore IT outsourcing engagement. Journal of Global Operations and Strategic Sourcing, Vol. 10 No. 2, pp. 255-278.

Niu, K. (2010), Industrial cluster involvement and organizational adaptation. Competitiveness Review, Vol. 20 , No. 5, pp. 395-406.

Nohrstedt, D., and Bodin, Ö. (2020), Collective action problem characteristics and partner uncertainty as drivers of social tie formation in collaborative networks. Policy Studies Journal, Vol. 48, No. 4, pp. 1082-1108.

Ocampo, L., Ebisa, J.A., Ombe, J., and Geen Escoto, M. (2018), Sustainable ecotourism indicators with fuzzy Delphi method - A Philippine perspective. Ecological Indicators, Vol. 93, pp. 874-888.

Oprime, P.C., Tristão, H.M., and Pimenta, M.L. (2011), Relationships, cooperation and development in a Brazilian industrial cluster. International Journal of Productivity and Performance Management, Vol. 60 No. 2, pp. 115-131. Papa, A., Chierici, R., Ballestra, L.V., Meissner, D., and Orhan, M.A. (2020), Harvesting reflective knowledge exchange for inbound open innovation in complex collaborative networks: an empirical verification in Europe. Journal of Knowledge Management.

Peng, T.J.A., Yen, M. H., and Bourne, M. (2018), How rival partners compete based on cooperation?. Long Range Planning, Vol. 51, No. 2, pp. 351-383.

Pessot, E., Zangiacomi, A., Berkers, F., Hidalgo-Carvajal, D., Weerdmeester, R., and Fornasiero, R. (2019), Investigating Supply Chains Models and Enabling Technologies Towards Collaborative Networks. IFIP Advances in Information and Communication Technology, Vol. 568, pp. 335-343.

Petter, R.R.H., Resende, L.M., de Andrade Júnior, P.P., and Horst, D. J. (2014), Systematic review: an analysis model for measuring the coopetitive performance in horizontal cooperation networks mapping the critical success factors and their variables. The Annals of regional science, Vol. 53, No. 1, pp. 157-178.

Polyantchikov, I., Shevtshenko, E., Karaulova, T., Kangilaski, T., and Camarinha-Matos, L.M. (2017), Virtual enterprise formation in the context of a sustainable partner network. Industrial management \& data systems, Vol. 117 No. 7, pp. 1446-1468.

Pouly, M., Monnier, F., and Bertschi, D. (2005, September). Success and failure factors of collaborative networks of SME. In Working Conference on Virtual Enterprises (pp. 597-604). Springer, Boston, MA.

Qiang, G., Cao, D., Wu, G., Zhao, X., and Zuo, J. (2021). Dynamics of Collaborative Networks for Green Building Projects: Case Study of Shanghai. Journal of Management in Engineering, Vol. 37, No. 3, pp. 05021001.

Ramayah, T., Wai Chow Lee, J., and Boey Chyaw In, J. (2011), Network collaboration and performance in the tourism sector, Vol. 5, pp. 411-428.

Ramström, J. (2008), Inter-organizational meets inter-personal: An exploratory study of social capital processes in 
relationships between Northern European and ethnic Chinese firms. Industrial Marketing Management, Vol. 37, No. 5, pp. 502-512.

Rank, O.N., Robins, G.L., and Pattison, P.E. (2010), Structural Logic of Intraorganizational Networks. Organization Science, Vo. 21, No. 3, pp. 745-764.

Rezaei, J. (2015), Best-worst multi-criteria decision-making method. Omega, Vol. 53, pp. 49-57.

Rezaei, J. (2016), Best-worst multi-criteria decision-making method: Some properties and a linear model. Omega, Vol. 64, pp. 126-130.

Ricciardi, F., Zardini, A., and Rossignoli, C. (2018), Business network commons and their fragilities: Emerging configurations of local organizational fields. Journal of Business Research, Vol. 89, pp. 328-335.

Rodgers, W., Degbey, W.Y., Housel, T.J., and Arslan, A. (2020), Microfoundations of collaborative networks: The impact of social capital formation and learning on investment risk assessment. Technological Forecasting and Social Change, Vol. 161, pp. 120295.

Rosas, J., Macedo, P., and Camarinha-Matos, L.M. (2011), Extended competencies model for collaborative networks. Production Planning \& Control, Vol. 22, No. 5-6, pp. 501-517.

Sacomano Neto, M., and Truzzi, O.M.S. (2009), Posicionamento estrutural e relacional em redes de empresas: uma análise do consórcio modular da indústria automobilística. Gestão \& Produção, Vol. 16, No. 4, pp. 598-611.

Salah, S.B., Yahia, W.B., Ayadi, O., and Masmoudi, F. (2017, March), Definition and classification of collaborative network: MCDM approaches for partner selection problem. In International Conference Design and Modeling of Mechanical Systems (pp. 733-744), Springer, Cham.

Salamat, V.R., Aliahmadi, A., Pishvaee, M.S., Hafeez, K., (2018), A robust fuzzy possibilistic approach for partner selection in international strategic alliance. Decision Science Letters, Vol. 7, pp. 481-502.

Schardosin, F.Z., De Rolt, C.R., Batista, A.M.L., Penz, D., Amorin, B., and Bier, C. A. (2020, April). Interorganizational collaborative networks: a systematic review. In 2020 International Conference on Technology and Entrepreneurship-Virtual (ICTE-V) (pp. 1-8). IEEE.

Sedaghat, R. (2019), Investigation of Factors Affecting Pistachio Orchards' Productivity in Kerman Province. Journal of Nuts, Vol. 10, No. 1, pp. 57-70.

Semnani, S.S.E., Dadfar, H., and Brege, S. (2015), The role of export clusters in export performance of SMEs: The case of Iranian energy industry. Quality Innovation Prosperity, Vol. 19, No. 2, pp. 137-160.

Soda, G., Stea, D., and Pedersen, T. (2019), Network structure, collaborative context, and individual creativity. Journal of Management, Vol. 45, No. 4, pp. 1739-1765.

Song, R., Xu, H., and Cai, L. (2019), Academic collaboration in entrepreneurship research from 2009 to 2018: A multilevel collaboration network analysis. Sustainability, Vol. 11, No. 19, pp. 5172.

Segato, F., and Raab, J. (2019), Mandated network formation. International Journal of Public Sector Management, Vol. 32 No. 2, pp. 191-206.

Sydow, J., Wirth, C., and Helfen, M. (2020), Strategy emergence in service delivery networks: Network-oriented human resource management practices at German airports. Human Resource Management Journal, Vol. 30, No. 4, pp. 566-585.

Tálamo, J.R., and Carvalho, M.M. de. (2010), Enterprise networks focused on innovation: a exploratory study. Gestão \& Produção, Vol. 17, No. 4, pp. 747-760.

Tan, J., Wang, L., Zhang, H., and Li, W. (2020), Disruptive innovation and technology ecosystem: The evolution of the intercohesive public-private collaboration network in Chinese telecommunication industry. Journal of Engineering and Technology Management, Vol. 57, pp. 101573.

Thomas, A., Morris, W., Haven-Tang, C., Francis, M., and Byard, P. (2021). Smart Systems and Collaborative Innovation Networks for Productivity Improvement in SMEs. Journal of Open Innovation: Technology, Market, and Complexity, Vol. 7, No. 1, pp. 3-20.

Thomson, A.M., and Perry, J.L. (2006), Collaboration Processes: Inside the Black Box. Public Administration Review, Vol. 66 , No. s1, pp. 20-32.

UNIDO. (2003), Development of Clusters and Networks of SMEs: A Guide to Export Consortia.

Uster, A., Beeri, I., and Vashdi, D. (2019), Don't push too hard. Examining the managerial behaviours of local authorities in collaborative networks with nonprofit organisations. Local Government Studies, Vol. 45, No. 1, pp. 124-145.

van den Heuvel, R., van de Wetering, R., Bos, R., and Trienekens, J. (2020), Identification of IT-Needs to Cope with Dynamism in Collaborative Networked Organizations: A Case Study. Digital Business Transformation, pp. 219-236.

Vuletic, T., Whitfield, R.I., Wang, W., Duffy, A., Gatchell, S., Prins, H., and Leer-Andersen, M. (2017), Improving the creation and management of collaborative networks within the European maritime sector. Journal of Industrial Information Integration, Vol. 8, pp. 22-37.

Wang, Y., and Yeo, G.T. (2018), Intermodal route selection for cargo transportation from Korea to Central Asia by adopting Fuzzy Delphi and Fuzzy ELECTRE I methods. Maritime Policy and Management, Vol. 45, No. 1, pp. 318 . 
Wang, L., Ma, L., Wu, K.J., Chiu, A.S. and Nathaphan, S., 2018. Applying fuzzy interpretive structural modeling to evaluate responsible consumption and production under uncertainty. Industrial Management and Data Systems, Vol. 118, No. 2, pp. 432-462.

Wang, C., and Hu, Q. (2020), Knowledge sharing in supply chain networks: Effects of collaborative innovation activities and capability on innovation performance. Technovation, Vol. 94-95, pp. 102010.

Wen, J., Qualls, W.J., and Zeng, D. (2020), Standardization Alliance Networks, Standard-Setting Influence, and New Product Outcomes. Journal of Product Innovation Management, Vol. 37, No. 2, pp. 138-157.

Wu, W.Y., Shih, H.A., and Chan, H.C. (2009), The analytic network process for partner selection criteria in strategic alliances. Expert Systems with Applications, Vol. 36, No. 3, pp. 4646-4653.

Yoon, C., Lee, K., Yoon, B., and Toulan, O. (2017), Typology and success factors of collaboration for sustainable growth in the IT service industry. Sustainability, Vol. 9, No. 11, pp. 212-232.

You, W., Shu, H., and Luo, S. (2018), Competition, cooperation, and performance: an empirical investigation of Chinese online sellers. Information Systems and e-Business Management, Vol. 16, No. 4, pp. 743-760.

Zade. L. A., (1965), Fuzzy sets. Information and Control, Vol. 8, No. 3, pp. 338-353.

Zavadskas, E.K., Turskis, Z., Antucheviciene, J., and Zakarevicius, A. (2012), Optimization of weighted aggregated sum product assessment. Elektronika ir elektrotechnika, Vol. 122, No. 6, pp. 3-6.

Zeng, S.X., Xie, X.M., and Tam, C.M. (2010), Relationship between cooperation networks and innovation performance of SMEs. Technovation, Vol. 30, No. 3, pp. 181-194.

Zhang, J. (2017), Evaluating regional low-carbon tourism strategies using the fuzzy Delphi-analytic network process approach. Journal of Cleaner Production, Vol. 141, pp. 409-419. 
Phase (1). Initial Screening

1.1. Literature review to identify capabilities to design and form collaborative networks 1.2. Screening and selecting the highlyreferenced factors/capabilities

Phase (2). Data Gathering

2.1. Identifying experts in Pistachio industry and academics with the knowledge of collaboration in global networks

2.2. Implementing two round Delphi fuzzy method; Eq. (1) and (2)

2.3. Extracting capabilities with defuzzied values higher than threshold

Phase (4). Formation

4.1. Identifying the characteristics of key countries to formalise collaborative network in pistachio industry

4.2. Prioritising the alternatives by WASPAS method; Eq. (5) to (13)

4.3. Analysing the results and discussion

Phase (3). Capabilities analysis
3.1. Implementing BWM method on selected
capabilities from (2.3)
3.2. Identifying the weights of each capability
in collaborative networks formation; $\mathbf{E q}$.
(3)
3.3. Measuring the consistency ratio of the
experts and checking the validity of the
results via Eq. (4)
3.4. Aggregating the weights of each
capability resulted from Delphi fuzzy
and BWM by arithmetic mean.

Figure 1. Research Methodology 


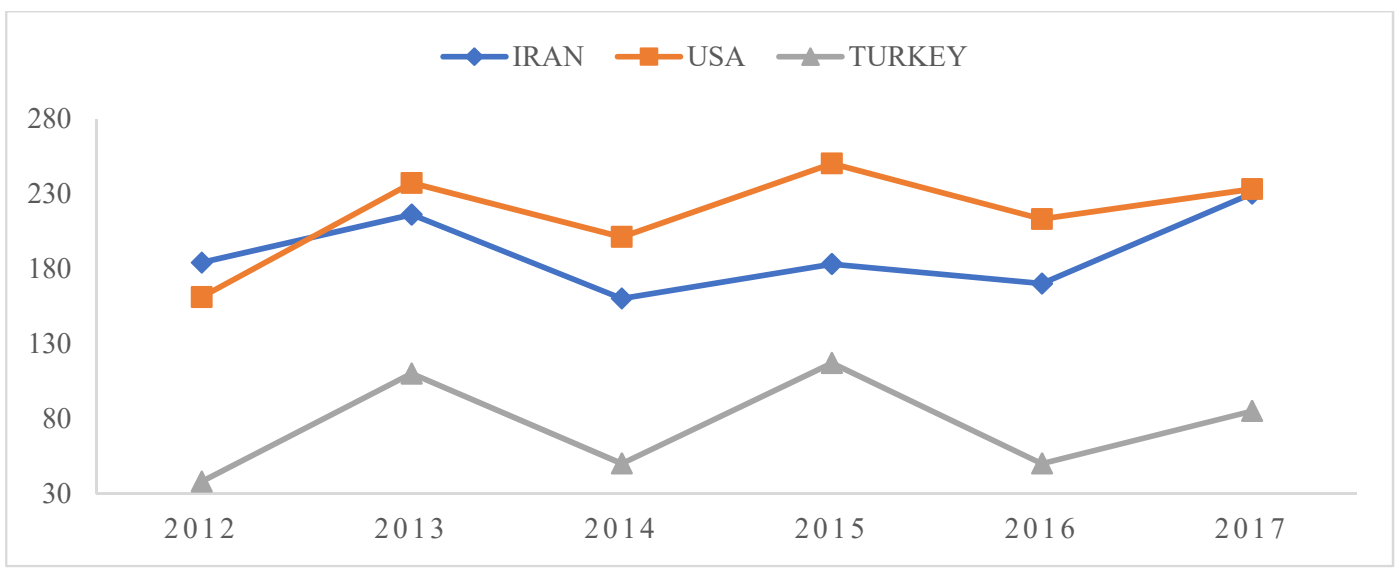

Figure 2. The production trend of three main competitors for pistachio during 2012-2017 


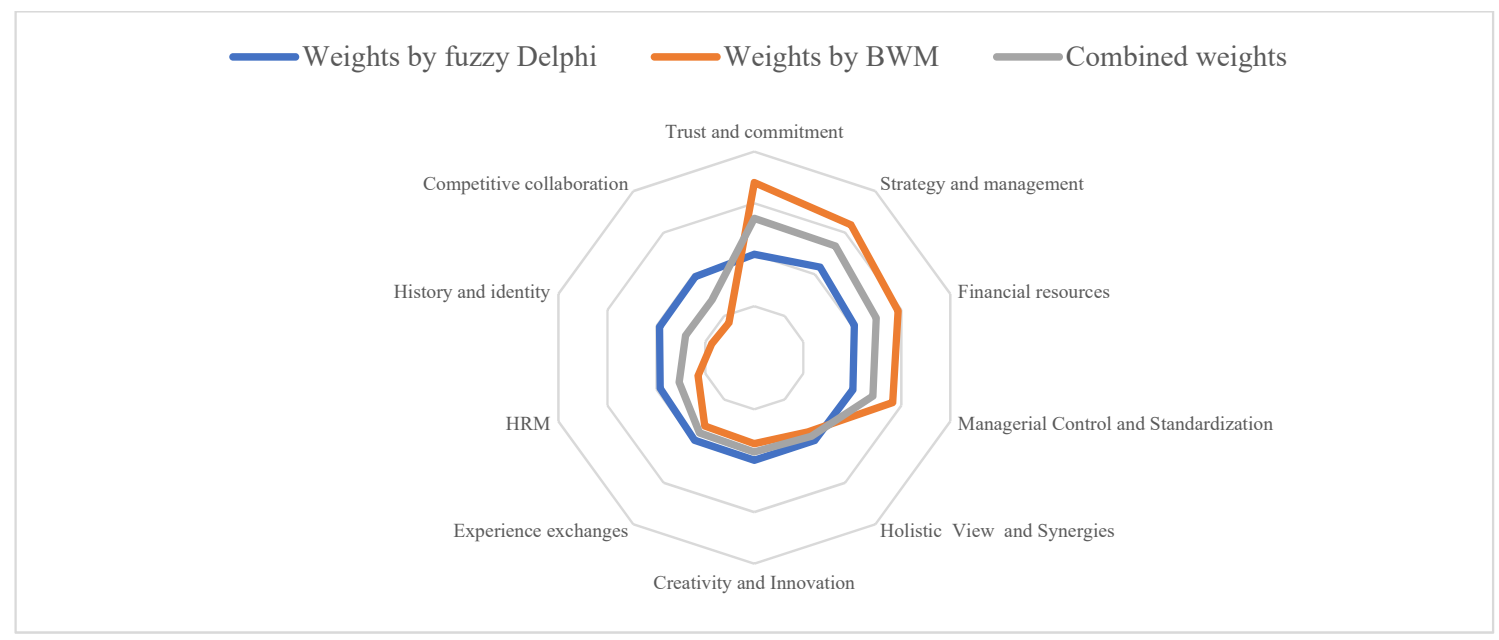

Figure 3. Key capabilities importance and weight for collaborative networks successful formation 
Table 1. Collaborative networks: a summary of the literature review

\begin{tabular}{|c|c|c|c|}
\hline $\begin{array}{c}\text { Research } \\
\text { Type }\end{array}$ & Researcher(s) and year & Issue/ Studied variable(s) & Methods used \\
\hline \multirow{14}{*}{ 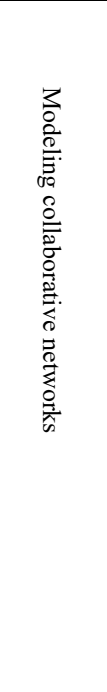 } & (Lundberg, 2010) & Regional strategic networks & \multirow{3}{*}{ Empirical research } \\
\hline & (Chang et al., 2010) & Social capital, cooperative performance, collaboration & \\
\hline & (Cambra-Fierro et al., 2011) & Inter-firm market orientation (IMO) & \\
\hline & (Adobor, 2011) & Inter-firm strategic alliance & \multirow{5}{*}{$\begin{array}{l}\text { Theory of group behavior } \\
\text { Cluster supply chain } \\
\text { Survey- Modeling } \\
\text { Value net analysis } \\
\text { Decision Framework- easy- } \\
\text { to-use typology }\end{array}$} \\
\hline & (Li et al., 2012) & Horizontal cooperation & \\
\hline & (Vuletic et al., 2017) & The needs for operational collaboration & \\
\hline & (You et al., 2018) & Vertical and horizontal collaborative networks & \\
\hline & (Martin et al., 2018) & $\begin{array}{l}\text { Horizontal cooperation between logistics service providers in road } \\
\text { transportation }\end{array}$ & \\
\hline & (Salamat et al., 2018) & & $\begin{array}{l}\text { Robust Fuzzy Possibilistic } \\
\text { AHP }\end{array}$ \\
\hline & (Andres et al., 2018) & $\begin{array}{l}\text { Strategies alignment and the collaborative emotion models } \\
\text { The role of trust to the sustainability of collaborative processes }\end{array}$ & \multirow{3}{*}{$\begin{array}{l}\text { Modeling framework to } \\
\text { assess strategies alignment } \\
\text { Narrative analysis } \\
\text { Empirical examination } \\
\text { Systematic literature review, }\end{array}$} \\
\hline & (Kimbu et al., 2019) & Human capital management (HCM) & \\
\hline & (Uster et al., 2019) & Managerial behaviors of local managers & \\
\hline & (Schardosin et al., 2020) & Collaborative networks studies & $\begin{array}{l}\text { Systematic literature review, } \\
\text { Social Network Analysis } \\
\text { (SNA) }\end{array}$ \\
\hline & (Qiang et al., 2021) & $\begin{array}{l}\text { Dynamics of Collaborative Networks for environmental } \\
\text { sustainability }\end{array}$ & SNA \\
\hline \multirow{9}{*}{ 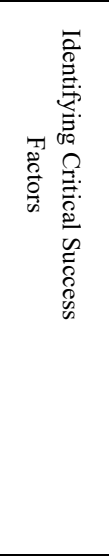 } & (Lin and Sun, 2010b) & Driving forces behind the growth of national industrial clusters & \multirow{4}{*}{$\begin{array}{l}\text { Decision Making Trial and } \\
\text { Evaluation Laboratory } \\
\text { (DEMATEL) } \\
\text { Quantitative analysis } \\
\text { partial least squares- } \\
\text { structural equation modeling } \\
\text { (PLS-SEM) }\end{array}$} \\
\hline & (Oprime et al., 2011) & Functional and surrounding factors of clusters & \\
\hline & (Rosas et al., 2011) & Categorising hard and soft competencies in collaboration & \\
\hline & (Ramayah et al., 2011) & Factors influencing collaborations in the tourism industry & \\
\hline & $\begin{array}{l}\text { (Leitner et al., 2011) } \\
\text { (Petter et al., 2014) }\end{array}$ & $\begin{array}{l}\text { Influential factors of collaboration in the shipping industry } \\
\text { Critical success factors in horizontal cooperation }\end{array}$ & \multirow{3}{*}{$\begin{array}{l}\text { Systematic Review } \\
\text { Survey } \\
\text { Bibliometric and systematic } \\
\text { review analysis }\end{array}$} \\
\hline & (Graça et al., 2017) & Performance indicators & \\
\hline & (Appio et al., 2017) & Influential factors of collaboration & \\
\hline & (Wang \& Hu, 2020) & $\begin{array}{l}\text { Critical factors influencing firm's innovation performance in supply } \\
\text { chain networks }\end{array}$ & $\begin{array}{l}\text { Hierarchical Multiple } \\
\text { Regression-Moderated } \\
\text { Multiple Regression }\end{array}$ \\
\hline & (Thomas et al., 2021) & Collaborative Innovation Networks for Productivity Improvement & Survey analysis \\
\hline \multirow{8}{*}{ 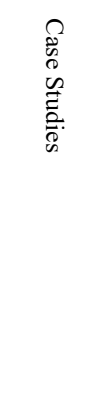 } & (Gomes-Casseres, 2015) & Re-mixing of business assets & \multirow{4}{*}{$\begin{array}{l}\text { Semi-structured interviews } \\
\text { Extensive analysis of } \\
\text { published studies- interview } \\
\text { Longitudinal study }\end{array}$} \\
\hline & (Semnani et al., 2015) & Export clusters and exports performance & \\
\hline & (Herczeg et al., 2018) & Industrial symbiosis & \\
\hline & (Felzensztein et al., 2018) & Inter-firm cooperation in an export-oriented regional cluster & \\
\hline & (Pessot et al., 2019) & Business models affecting supply chain configurations & $\begin{array}{l}\text { Multiple case studies } \\
\text { analysis }\end{array}$ \\
\hline & (Huang et al., 2020) & Performance of individual policy actors embedded in the network & Examination with a dataset \\
\hline & (Papa et al., 2020) & $\begin{array}{l}\text { Open innovation and big data analytics on reflective knowledge } \\
\text { exchange }\end{array}$ & $\begin{array}{l}\text { least-squares regression } \\
\text { analysis }\end{array}$ \\
\hline & (Dobrescu et al., 2021) & $\begin{array}{l}\text { Improving supply chain management by applying hierarchical } \\
\text { networked control systems }\end{array}$ & $\begin{array}{l}\text { hierarchical networked } \\
\text { control systems }\end{array}$ \\
\hline
\end{tabular}


Table 2. Experts Profile

\begin{tabular}{|c|c|c|c|}
\hline $\begin{array}{c}\text { Expert } \\
\text { affiliation } \\
\end{array}$ & $\begin{array}{c}\text { Number of } \\
\text { experts }\end{array}$ & Reason (advantages) & Limitations (disadvantages) \\
\hline $\begin{array}{c}\text { Owner/ } \\
\text { Managers }\end{array}$ & 5 & $\begin{array}{l}\text { - experience in the pistachio export industry } \\
\text { - knowledgeable of the product's quality } \\
\text { - knowledge of the internal market }\end{array}$ & $\begin{array}{l}\text { - limited knowledge of how to conduct business in the } \\
\text { international market } \\
\text { - Not familiar with decision-making models } \\
\text { - Not familiar with research methods }\end{array}$ \\
\hline $\begin{array}{c}\text { Authorities/ } \\
\text { Officials }\end{array}$ & 5 & $\begin{array}{l}\text { - good understanding of the industry } \\
\text { - familiar with the export process } \\
\text { - familiar with international markets and } \\
\text { regulations }\end{array}$ & $\begin{array}{l}\text { - limited knowledge of how to develop international } \\
\text { partnerships } \\
\text { - limited knowledge regarding the value of creating } \\
\text { networks } \\
\text { - Not familiar with decision-making models }\end{array}$ \\
\hline $\begin{array}{c}\text { Local } \\
\text { academics }\end{array}$ & 4 & $\begin{array}{l}\text { - Familiar with decision-making models and } \\
\text { research methods } \\
\text { - high knowledge in collaborative networks } \\
\text { formation }\end{array}$ & - Limited executive experience \\
\hline
\end{tabular}


Table 3. TFN for Likert Spectrum

\begin{tabular}{ccccccc}
\hline $\begin{array}{c}\text { Completely } \\
\text { Insignificant }\end{array}$ & $\begin{array}{c}\text { Highly } \\
\text { Insignificant }\end{array}$ & $\begin{array}{c}\text { Moderately } \\
\text { Insignificant }\end{array}$ & Medium & $\begin{array}{c}\text { Moderately } \\
\text { Significant }\end{array}$ & $\begin{array}{c}\text { Highly } \\
\text { Significant }\end{array}$ & $\begin{array}{c}\text { Completely } \\
\text { Significant }\end{array}$ \\
$(0,0,0.1)$ & $(0,0.1,0.3)$ & $(0.1,0.3,0.5)$ & $(0.3,0.5,0.75)$ & $(0.5,0.75,0.9)$ & $(0.75,0.9,1)$ & $(0.9,0.9,1)$ \\
\hline
\end{tabular}


Table 4. CI values

\begin{tabular}{cccccccccc}
\hline $\mathrm{A}_{\mathrm{BW}}$ & 1 & 2 & 3 & 4 & 5 & 6 & 7 & 8 & 9 \\
$\mathrm{CI}$ & 0.00 & 0.44 & 1.00 & 1.63 & 2.30 & 3.00 & 3.73 & 4.47 & 5.23 \\
\hline
\end{tabular}


Table 5. A summary of the key capabilities for developing a collaborative network (Based on Petter et al., 2014)

\begin{tabular}{|c|c|c|c|}
\hline $\begin{array}{c}\text { key } \\
\text { capabilities }\end{array}$ & resources/assets & Some Related References & $\begin{array}{l}\text { No of } \\
\text { Refer }\end{array}$ \\
\hline 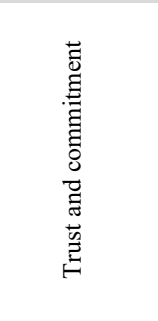 & $\begin{array}{l}\text { - Close interactions amongst partnering } \\
\text { companies; } \\
\text { - Open sharing and protection of } \\
\text { information amongst partners; } \\
\text { - Senior managers' commitment to building } \\
\text { trust and mitigation of risk for all partners in } \\
\text { the network; }\end{array}$ & $\begin{array}{l}\text { (Msanjila and Afsarmanesh, 2007), (Jiang et al., 2008), } \\
\text { (Ramström, 2008), (Caglio and Ditillo, 2008), (Sacomano Neto } \\
\text { and Serra Truzzi, 2009), (Lin and Sun, 2010), (Niu, 2010), } \\
\text { (Chang et al., 2010), (Tálamo and Carvalho, 2010), (Rank et al., } \\
\text { 2010), (Zeng et al., 2010), (Moeller, 2010), (Catalina, 2010), } \\
\text { (Lundberg, 2010), (Chow and Yau, 2010), (Cambra-Fierro et al., } \\
\text { 2011), (Adobor, 2011), (Ramayah et al., 2011), (Petter et al., } \\
\text { 2014), (Vuletic et al., 2017), (You et al., 2018), (Bodin et al., } \\
\text { 2020) }\end{array}$ & 38 \\
\hline 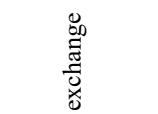 & - Commitment for $\quad$ co-creation, & & \\
\hline 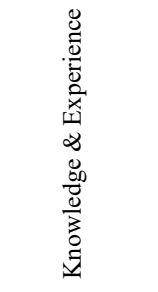 & $\begin{array}{l}\text { disseminating, and management of } \\
\text { knowledge, } \\
\text { - Sharing best practices and experiential } \\
\text { learning; } \\
\text { - Adopting common vocabulary and } \\
\text { creating knowledge ontologies. }\end{array}$ & $\begin{array}{l}\text { (Jiang et al., 2008), (Wu et al., 2009), (Sacomano Neto and Serra } \\
\text { Truzzi, 2009), (Lundberg, 2010), (Lin and Sun, 2010), (Chang et } \\
\text { al., 2010), (Cambra-Fierro et al., 2011), (Petter et al., 2014), } \\
\text { (Vuletic et al., 2017), (Peng et al., 2018), (Bodin et al., 2020), } \\
\text { (Hjertvikrem and Fitjar, 2021) }\end{array}$ & 29 \\
\hline 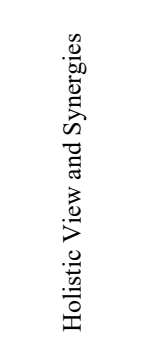 & $\begin{array}{l}\text { - Realising synergy for developing } \\
\text { collaborative architecture; } \\
\text { - Clearly defined structure to support the } \\
\text { underlying process for cooperation; } \\
\text { - Holistic or end-to-end view to ensuring } \\
\text { cooperation in the network; } \\
\text { - Management efforts to eliminate barriers } \\
\text { and limitations; } \\
\text { - Agreed KPI's to assess the results of } \\
\text { collaboration over time. }\end{array}$ & $\begin{array}{l}\text { (Sacomano Neto and Serra Truzzi, 2009), (Niu, 2010), (Chang et } \\
\text { al., 2010), (Moeller, 2010), (Cambra-Fierro et al., 2011), } \\
\text { (Lundberg, 2010), (Adobor, 2011), (Petter et al., 2014), (Gomes- } \\
\text { Casseres, 2015), (Vuletic et al., 2017), (Ricciardi et al., 2018), } \\
\text { (Bodin et al., 2020), (Al Hattab, 2021) }\end{array}$ & 24 \\
\hline 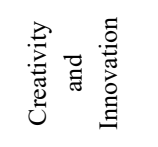 & $\begin{array}{l}\text { - Developing creativity capability to address } \\
\text { the market needs; } \\
\text { - Digital and information technologies to } \\
\text { initiate and implement innovation. }\end{array}$ & $\begin{array}{l}\text { (Lin and Sun, 2010), (Chang et al., 2010), (Zeng et al., 2010), } \\
\text { (Oprime et al., 2011), (Cambra-Fierro et al., 2011), (Petter et al., } \\
\text { 2014), (Soda et al., 2018), (Papa et al., 2020) }\end{array}$ & 22 \\
\hline 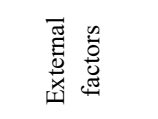 & $\begin{array}{l}\text { - Partner companies infrastructure; } \\
\text { - The proximity of the network/cluster. }\end{array}$ & $\begin{array}{l}\text { (Sacomano Neto and Serra Truzzi, 2009), (Lundberg, 2010), } \\
\text { (Moeller, 2010), (Cambra-Fierro et al., 2011), (Petter et al., } \\
\text { 2014), (Peng et al., 2018), (Schardosin et al., 2020) }\end{array}$ & 21 \\
\hline 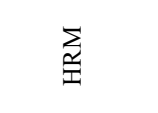 & $\begin{array}{l}\text { - Training human resource; } \\
\text { - Commitment to talent management }\end{array}$ & $\begin{array}{l}\text { (Caglio and Ditillo, 2008), (Wu et al., 2009), (Moeller, 2010), } \\
\text { (Oprime et al., 2011), (Petter et al., 2014), (Ricciardi et al., 2018), } \\
\text { (Sydow et al., 2020) }\end{array}$ & 21 \\
\hline 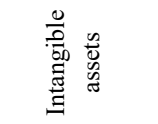 & $\begin{array}{l}\text { - Branding; } \\
\text { - Intellectual capital management. }\end{array}$ & $\begin{array}{l}\text { (Caglio and Ditillo, 2008), (Wu et al., 2009), (Moeller, 2010), } \\
\text { (Oprime et al., 2011), (Petter et al., 2014), (Ricciardi et al., 2018), } \\
\text { (Papa et al., 2020) }\end{array}$ & 21 \\
\hline 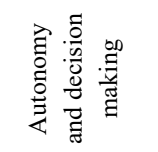 & $\begin{array}{l}\text { - Formalisation of relations and governance; } \\
\text { - Skills for managing international relations; } \\
\text { - Promoting decision-making at all levels. }\end{array}$ & $\begin{array}{l}\text { (UNIDO, 2003), (Caglio and Ditillo, 2008), (Sacomano Neto } \\
\text { and Serra Truzzi, 2009), (Oprime et al., 2011), (Petter et al., } \\
\text { 2014), (Polyantchikov et al., 2017), (Martin et al., 2018), } \\
\text { (Schardosin et al., 2020) }\end{array}$ & 16 \\
\hline 总㤩害 & $\begin{array}{l}\text { - Company identity and characteristics } \\
\text { (history, value, and size); } \\
\text { - Promoting cultural integration; }\end{array}$ & $\begin{array}{l}\text { (UNIDO, 2003), (Lin and Sun, 2010), (Niu, 2010), (Catalina, } \\
\text { 2010), (Lundberg, 2010), (Petter et al., 2014), (Peng et al., 2018), } \\
\text { (Schardosin et al., 2020) }\end{array}$ & 15 \\
\hline 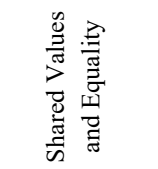 & $\begin{array}{l}\text { - Promoting equality amongst partners } \\
\text { - Shared vision and agreed goals on how to } \\
\text { do business; }\end{array}$ & $\begin{array}{l}\text { (UNIDO, 2003), (Caglio and Ditillo, 2008), (Petter et al., 2014), } \\
\text { (Gomes-Casseres, 2015), (Soda et al., 2018), (Papa et al., 2020), } \\
\text { (Hjertvikrem and Fitjar, 2021) }\end{array}$ & 15 \\
\hline
\end{tabular}




\begin{tabular}{|c|c|c|c|}
\hline $\begin{array}{c}\text { key } \\
\text { capabilities }\end{array}$ & resources/assets & Some Related References & $\begin{array}{l}\text { No of } \\
\text { Refer }\end{array}$ \\
\hline 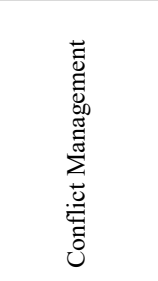 & $\begin{array}{l}\text { - Desire to manage internal conflicts in } \\
\text { network amicably; } \\
\text { - Manage diversity in the network; } \\
\text { - Agreeing to a legal framework for } \\
\text { cooperation between companies; }\end{array}$ & $\begin{array}{l}\text { (UNIDO, 2003), (Tálamo and Carvalho, 2010), (Catalina, 2010), } \\
\text { (Lundberg, 2010), (Petter et al., 2014), (Semnani et al., 2015), } \\
\text { (Ricciardi et al., 2018), (Bodin et al., 2020), (Al Hattab, 2021) }\end{array}$ & 14 \\
\hline 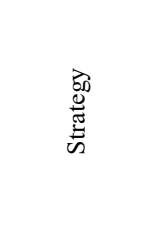 & $\begin{array}{l}\text { - Ability to recognise collective } \\
\text { competencies and converting these to gain } \\
\text { competitive advantages; } \\
\text { - Identifying opportunities, market } \\
\text { developments, and regional economic and } \\
\text { political climate. }\end{array}$ & $\begin{array}{l}\text { (Caglio and Ditillo, 2008), (Sacomano Neto and Serra Truzzi, } \\
\text { 2009), (Lin and Sun, 2010), (Lundberg, 2010), (Moeller, 2010), } \\
\text { (Niu, 2010), (Oprime et al., 2011), (Cambra-Fierro et al., 2011), } \\
\text { (Petter et al., 2014), (Vuletic et al., 2017), (Soda et al., 2018), } \\
\text { (Bodin et al., 2020) }\end{array}$ & 14 \\
\hline 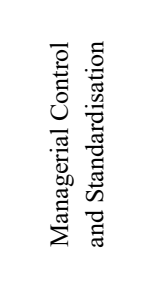 & $\begin{array}{l}\text { - Defining clear roles and control } \\
\text { mechanisms } \\
\text { - Working toward standardisation; } \\
\text { - Developing formal and informal business- } \\
\text { centric communicational standards to avoid } \\
\text { confusion; } \\
\text { - Where possible, automate using digital } \\
\text { technology. }\end{array}$ & $\begin{array}{l}\text { (UNIDO, 2003), (Niu, 2010), (Catalina, 2010), (Moeller, 2010), } \\
\text { (Petter et al., 2014), (Soda et al., 2018), (Ricciardi et al., 2018), } \\
\text { (Wen et al., 2020) }\end{array}$ & 13 \\
\hline 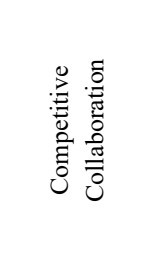 & $\begin{array}{l}\text { - Promote collaborative behavior between } \\
\text { partners; } \\
\text { - Promoting opportunities and competitive } \\
\text { actions; } \\
\text { - Adopt managerially and IT for promoting } \\
\text { communication and integration amongst } \\
\text { network members. }\end{array}$ & $\begin{array}{l}\text { (Camarinha-Matos et al., 2009), (Lin and Sun, 2010), (Niu, } \\
\text { 2010), (Tálamo and Carvalho, 2010), (Zeng et al., 2010), } \\
\text { (Moeller, 2010), (Oprime et al., 2011), (Adobor, 2011), (Petter et } \\
\text { al., 2014), (Peng et al., 2018), (Camarinha-Matos et al., 2019), } \\
\text { (Wen et al., 2020) }\end{array}$ & 12 \\
\hline 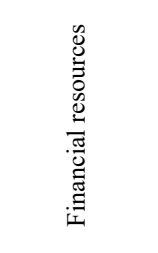 & $\begin{array}{l}\text { - Accessing business talent (beyond } \\
\text { agricultural knowledge); } \\
\text { - Better visibility of cash flow amongst } \\
\text { partners; } \\
\text { - Cost efficiencies and reducing debts; } \\
\text { - Open book accounting to agree on cost and } \\
\text { profit share. }\end{array}$ & $\begin{array}{l}\text { (UNIDO, 2003), (Sacomano Neto and Serra Truzzi, 2009), (Niu, } \\
\text { 2010), (Lundberg, 2010), (Petter et al., 2014), (Soda et al., 2018), } \\
\text { (Wen et al., 2020) }\end{array}$ & 11 \\
\hline 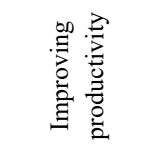 & $\begin{array}{l}\text { - Introduce modern methods to realised } \\
\text { productivity; } \\
\text { - Develop capacity and productivity KPIs } \\
\text { and track using technology. }\end{array}$ & $\begin{array}{l}\text { (Lundberg, 2010), (Moeller, 2010), (Lin and Sun, 2010), (Niu, } \\
\text { 2010), (Oprime et al., 2011), (Petter et al., 2014), (Peng et al., } \\
\text { 2018) }\end{array}$ & 9 \\
\hline 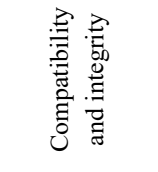 & $\begin{array}{l}\text { - Develop organisational flexibility to } \\
\text { become compatible with the network; } \\
\text { - Promote integrity. }\end{array}$ & $\begin{array}{l}\text { (Niu, 2010), (Petter et al., 2014), (Ricciardi et al., 2018), } \\
\text { (Camarinha-Matos et al., 2019) }\end{array}$ & 6 \\
\hline 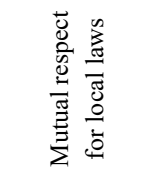 & $\begin{array}{l}\text { - Companies' independence in following } \\
\text { local laws and practices. }\end{array}$ & (Caglio and Ditillo, 2008), (Petter et al., 2014), (Peng et al., 2018) & 6 \\
\hline
\end{tabular}


Table 6. Integration and defuzzification

\begin{tabular}{cccc}
\hline Capability & & & \\
& Defuzzified values & Normal Weight & Code \\
\hline Trust and commitment & & & \\
\hline Holistic View and Synergies & 0.83 & 0.100 & $\mathrm{C}_{4}$ \\
Experiences exchange & 0.83 & 0.100 & $\mathrm{C}_{5}$ \\
History and identity & 0.82 & 0.099 & $\mathrm{C}_{7}$ \\
Sharing and equality & 0.80 & 0.097 & $\mathrm{C}_{10}$ \\
Conflict Management & 0.72 & & \\
Competitive collaboration & 0.75 & 0.097 & $\mathrm{C}_{8}$ \\
Managerial Control and Standardisation & 0.81 & 0.101 & $\mathrm{C}_{3}$ \\
Compatibility and integrity & 0.84 & & \\
Mutual respect for local laws & 0.72 & & \\
Autonomy and decision making & 0.73 & & \\
External and unfamiliar factors & 0.72 & 0.108 & $\mathrm{C}_{1}$ \\
Strategy and management & 0.66 & & \\
Improving productivity & 0.90 & 0.100 & $\mathrm{C}_{6}$ \\
Creativity and Innovation & 0.70 & 0.102 & $\mathrm{C}_{2}$ \\
Financial resources & 0.83 & 0.097 & $\mathrm{C}_{9}$ \\
HRM & 0.85 & & \\
\hline Intangible assets & 0.80 & 0.65 & \\
\hline
\end{tabular}


Table 7. Weights by BWM

\begin{tabular}{|c|c|c|c|c|c|c|c|c|}
\hline $\mathbf{W} / \mathbf{E}$ & $\begin{array}{c}\text { Group } \\
\text { Expert } 1\end{array}$ & $\begin{array}{c}\text { Group } \\
\text { Expert } 2\end{array}$ & $\begin{array}{c}\text { Group } \\
\text { Expert } 3\end{array}$ & $\begin{array}{c}\text { Group } \\
\text { Expert } 4\end{array}$ & $\begin{array}{c}\text { Group } \\
\text { Expert } 5\end{array}$ & $\begin{array}{c}\text { Group } \\
\text { Expert } 6\end{array}$ & $\begin{array}{c}\text { Group } \\
\text { Expert } 7\end{array}$ & average \\
\hline $\mathrm{w}_{1}$ & 0.13740360 & 0.1781 & 0.129991 & 0.10193 & 0.158873 & 0.201778 & 0.2079729 & 0.15943536 \\
\hline $\mathrm{W}_{2}$ & 0.14726170 & 0.255003 & 0.087795 & 0.118918 & 0.173628 & 0.100889 & 0.1802484 & 0.15196319 \\
\hline $\mathrm{W}_{3}$ & 0.13651930 & 0.148877 & 0.259982 & 0.128561 & 0.262795 & 0.12751 & 0.1360464 & 0.17147016 \\
\hline $\mathrm{W}_{4}$ & 0.27303860 & 0.116848 & 0.129991 & 0.237836 & 0.109265 & 0.105094 & 0.1351863 & 0.15817969 \\
\hline $\mathrm{W}_{5}$ & 0.05878350 & 0.085001 & 0.086661 & 0.10193 & 0.059657 & 0.091746 & 0.0909843 & 0.08210880 \\
\hline $\mathrm{W}_{6}$ & 0.04550643 & 0.056667 & 0.064996 & 0.080069 & 0.073457 & 0.103643 & 0.06845325 & 0.07039883 \\
\hline $\mathrm{W}_{7}$ & 0.06825964 & 0.038948 & 0.055297 & 0.081315 & 0.04862 & 0.105094 & 0.06759314 & 0.06644650 \\
\hline $\mathrm{W}_{8}$ & 0.04664056 & 0.041223 & 0.087795 & 0.052371 & 0.047873 & 0.035031 & 0.04506209 & 0.05085650 \\
\hline $\mathrm{W}_{9}$ & 0.05624904 & 0.028334 & 0.032498 & 0.063094 & 0.024804 & 0.050445 & 0.02253105 & 0.03970772 \\
\hline $\mathrm{W}_{10}$ & 0.03033762 & 0.051001 & 0.064996 & 0.033977 & 0.041029 & 0.078772 & 0.0459222 & 0.04943329 \\
\hline $\mathrm{A}_{\mathrm{bw}}$ & 9 & 9 & 8 & 8 & 9 & 8 & 9 & - \\
\hline CR & 0.10305545 & 0.182409178 & 0.14191946 & 0.10026622 & 0.104947419 & 0.14551387 & 0.183905468 & - \\
\hline
\end{tabular}

Blue indicates the Best criteria from each expert group perspective and green illustrates the worst criteria from each group of experts opinion 
Table 8. Final weights of capabilities

\begin{tabular}{cc}
\hline Capability & Combined weights \\
Trust and commitment & 0.135228174 \\
Strategy and management & 0.133985487 \\
Financial resources & 0.12439355 \\
Managerial Control and Standardisation & 0.120937256 \\
Holistic View and Synergies & 0.094213668 \\
Creativity and Innovation & 0.091531908 \\
Experience exchanges & 0.090426973 \\
HRM & 0.076766068 \\
History and identity & 0.070128263 \\
Competitive collaboration & 0.069627416 \\
\hline
\end{tabular}


Table 9. Decision, Normalised and Variance matrices for WASPAS

\begin{tabular}{cccccccccccccc}
\hline DMM & C1 & C2 & C3 & C4 & C5 & C6 & C7 & C8 & C9 & C10 \\
\hline Iran & 6 & 5.57 & 5.43 & 78.29 & 7.57 & 6 & 7.43 & 6.86 & 6.14 & 6.14 \\
Turkey & 5.14 & 5.43 & 5.43 & 5.86 & 4.86 & 5 & 6.86 & 6.14 & 6.43 & 7.57 \\
EU & 6.86 & 7 & 7 & 7.57 & 5.29 & 7.29 & 7.29 & 5.57 & 7 & 8.29 \\
USA & 8.43 & 8.29 & 7.71 & 8.29 & 5.43 & 7.57 & 8.14 & 5.57 & 8.14 & 8.14 \\
\hline Normal & $\mathrm{C} 1$ & $\mathrm{C} 2$ & $\mathrm{C} 3$ & $\mathrm{C} 4$ & $\mathrm{C} 5$ & $\mathrm{C} 6$ & $\mathrm{C} 7$ & $\mathrm{C} 8$ & $\mathrm{C} 9$ & $\mathrm{C} 10$ \\
\hline Iran & 0.44653 & 0.41721 & 0.41966 & 0.49890 & 0.64348 & 0.45823 & 0.49904 & 0.56617 & 0.44048 & 0.40487 \\
Turkey & 0.38253 & 0.40672 & 0.41966 & 0.40103 & 0.41312 & 0.38185 & 0.46075 & 0.50674 & 0.46128 & 0.49916 \\
EU & 0.51054 & 0.52432 & 0.54100 & 0.51806 & 0.44967 & 0.55675 & 0.4896 & 0.45970 & 0.5021 & 0.54664 \\
USA & 0.6273 & 0.62095 & 0.59588 & 0.567339 & 0.461575 & 0.57813 & 0.5467 & 0.45970 & 0.5839 & 0.53674 \\
\hline Variances & $\mathrm{C} 1$ & $\mathrm{C} 2$ & $\mathrm{C} 3$ & $\mathrm{C} 4$ & $\mathrm{C} 5$ & $\mathrm{C} 6$ & $\mathrm{C} 7$ & $\mathrm{C} 8$ & $\mathrm{C} 9$ & $\mathrm{C} 10$ \\
\hline Iran & 0.000498 & 0.000435 & 0.000440 & 0.000622 & 0.001035 & 0.000525 & 0.000623 & 0.000801 & 0.000485 & 0.000410 \\
Turkey & 0.000366 & 0.000414 & 0.000440 & 0.000402 & 0.000427 & 0.000365 & 0.000531 & 0.000642 & 0.000532 & 0.000623 \\
EU & 0.000652 & 0.000687 & 0.000732 & 0.000671 & 0.000506 & 0.000775 & 0.000599 & 0.000528 & 0.000630 & 0.000747 \\
USA & 0.000984 & 0.000964 & 0.000888 & 0.000805 & 0.000533 & 0.000836 & 0.000747 & 0.000528 & 0.000853 & 0.000720 \\
\hline
\end{tabular}


Table 10. Results of WASPAS

\begin{tabular}{|cccccc|}
\hline Country & Estimate variance in WSM & Estimate variance in WPM & Optimal $\lambda$ & Priority score & Rank \\
Iran & 0.000029 & 0.000059 & 0.666 & 0.474 & 3 \\
Turkey & 0.000020 & 0.000048 & 0.703 & 0.425 & 4 \\
EU & 0.000037 & 0.000069 & 0.653 & 0.512 & 2 \\
USA & 0.000052 & 0.000084 & 0.618 & 0.566 & 1 \\
\hline
\end{tabular}

